\title{
Contamination of the Surfaces of a Health Care Environment by Multidrug-Resistant (MDR) Bacteria
}

\author{
Laila Chaoui (D), ${ }^{1,2}$ RajaaAit Mhand, ${ }^{2}$ Fouad Mellouki, ${ }^{2}$ and Naima Rhallabi ${ }^{2}$ \\ ${ }^{1}$ Provincial Diagnostic Laboratory Epidemiological and Environmental Health, Provincial Health Delegation, \\ Mohammedia, Morocco \\ ${ }^{2}$ Research Unit Microbiology Hygiene Bioactives Molecules Laboratory Virology Microbiology Quality \\ and Biotechnology/Ecotoxicology Biodiversity, University Hassan II Casablanca, FSTM, Mohammedia, Morocco \\ Correspondence should be addressed to Laila Chaoui; chaoui.laila.labo@gmail.com
}

Received 20 May 2019; Revised 20 August 2019; Accepted 31 October 2019; Published 29 November 2019

Academic Editor: Michael McClelland

Copyright ( 92019 Laila Chaoui et al. This is an open access article distributed under the Creative Commons Attribution License, which permits unrestricted use, distribution, and reproduction in any medium, provided the original work is properly cited.

\begin{abstract}
Nosocomial infections (NIs) are known worldwide and remain a major problem despite scientific and technical advances in the field of health. The severity of the infection depends on the characteristics of the microorganisms involved and the high frequency of resistant pathogens in the hospital environment. The aim of this study is to determine the distribution of pathogenic bacteria (and their resistance to antibiotics) that spread on hospital surfaces, more specifically, on those of various departments in the Provincial Hospital Center (PHC) of Mohammedia, Morocco. A cross-sectional study was conducted from March 2017 to April 2018. Samples were collected by swabbing the hospital surfaces, and the isolated bacteria were checked for their susceptibility to antibiotics by the Kirby-Bauer disk diffusion method following the standards of the Clinical and Laboratory Standards Institute (CLSI). Among 200 swab samples, 176 (88\%) showed bacterial growth. Gram-negative isolates were predominant at 51.5\% (101/196), while the Gram-positives were at $48.5 \%$ (95/196). The main isolates are Enterobacteria weighted at 31.6\% (62/196), Staphylococcus aureus reaching 24\% (47/196), Pseudomonas aeruginosa at 9.2\% (18/196), and Acinetobacter spp. with 3.3\% (6/196). Moreover, the antimicrobial susceptibility profile of the isolates showed that about $31.7 \%(32 / 101)$ of the Gram-negative isolates were found to be MDR. This resistance is also high among isolates of $S$. aureus of which 44.7\% (20/47) were methicillin-resistant Staphylococcus aureus (MRSA). Contamination of hospital surfaces by MDR bacteria is a real danger to public health. The concept of environmental bacterial reservoir is a reality that requires strict compliance with current guidelines and recommendations for hand hygiene, cleaning, and disinfection of surfaces in hospitals.
\end{abstract}

\section{Background}

Nosocomial infections (NIs) represent a major public health problem, with their frequency, severity, economic and social costs, and also the difficulty of controlling them. According to the World Health Organization (WHO), an average of $8.7 \%$ of hospital patients have NIs. At any given moment, it can be verified that over 1.4 million people worldwide suffer from infectious complications acquired in hospital [1]. Generally, NIs can be endogenous originate-the patient's own flora is the source of the infection, or exogenous-the pathogen comes from other patients, staff, or the hospital environment: water, air, or surfaces [2].

The contamination of surfaces depends on their characteristics, such as whether they are smooth, porous, or rough and/or on their state, such as whether they are dry, wet, new, or old. It also constitutes an ecological niche of bacteria capable of forming biofilms. These bacteria on many surfaces in a hospital last from a few days to long periods that can even go beyond 90 days [3]. Numerous investigations made in hospitals have highlighted the possible place of the inert environment as a contamination reservoir of patients, namely, because of the presence of multidrug-resistant bacteria (MDR) [4].

In Morocco, the incidence and prevalence of NIs are rarely published. A survey conducted in 1994 on an extended sample of 24 hospitals showed that the determined prevalence is $4.1 \%$ in provincial hospitals, $7.7 \%$ in regional hospitals, and $10.3 \%$ at the University Hospital Center (UHC) [5]. The prevalence of NIs at the Ibn Sina Hospital in Rabat is 9.5\% and at the Ibn Rochd Casablanca Hospital Center it is 
$11.5 \%$. Recently, this situation has become complicated by the emergence of multidrug-resistant bacteria, which poses a difficult task for clinicians who have limited therapeutic schemes [6].

These studies have focused on a number of bacterial species, such as methicillin-resistant Staphylococcus aureus (MRSA), glycopeptide-resistant Enterococci (GRE), Acinetobacter baumannii, and Pseudomonas aeruginosa. Bhalla et al. showed that the hands of caregivers who come into contact with only the colonized/infected patients' environment were often contaminated with bacteria, 30\% of which were MRSA, 20\% were GRE, and 15\% were Gram-negative bacilli $[7,8]$. This is a matter of a nonnegligible mode of contamination by manual transmission between environment, caregiver, and patient.

As part of the microbiological surveillance of the hospital environment, the present study represents a major focus on NI control strategies. Its aim is to determine, for the first time, the distribution of bacterial pathogens (resistant to antibiotics) that are prevalent on hospital surfaces of various departments in the Provincial Hospital Center (PHC) of Mohammedia. This enables the generation of local and original data on the emergence of MDR bacteria that could be the source of the spread of nosocomial diseases.

\section{Materials and Methods}

2.1. Framework and Research Timelines. A transverse bacteriological study was conducted from 1 March 2017 to 30 April 2018, in a public provincial hospital in Mohammedia city (Morocco), which had a 148-bed capacity and an average occupancy rate of 49.96 in 2016. The prefecture of Mohammedia covers an area of $277 \mathrm{~km}^{2}$. It is located between two of the most important cities in Morocco the economic city of Casablanca $(25 \mathrm{~km}$ east) and the administrative city of Rabat ( $65 \mathrm{~km}$ west). The total population is 352,000 inhabitants (73\% urban and 27\% rural). All these characteristics make Mohammedia a city with specific health needs. These peculiarities guided the choice of the provincial hospital (the only one) of this city as the place for our study.

2.2. Study Site and Sampling. From five different departments (including the maternity, surgery, and medical wards, as well as the emergency and operating theatres), 241 surface samples were collected. Surface swab specimens were collected from predefined surfaces, such as operating tables, operating lights, beds, medical devices, floor, wall, and sinks, by using cotton swabs premoistened with sterile normal saline water according to ISO/DIS 14698-1 [9]. The choice of sampling points was made in consultation with the heads of departments and targeted the most critical and most representative locations in each department.

The collection was made in the early hours of the morning and transported in a cooler kept at $5 \pm 3^{\circ} \mathrm{C}$ to be analyzed at the Provincial Epidemiological Diagnosis and Environmental Hygiene Laboratory (LPDEHM) under the authority of the provincial health department of Mohammedia.
2.3. Isolation and Phenotypic Identification of Aerobic Bacteria. After the delivery of samples to the laboratory, each swab was immersed in a liquid nutrient broth (BHI) and incubated at $37 \pm 1^{\circ} \mathrm{C}$ for $24 \mathrm{~h}$. Growth was noted, and the swabs were further subcultured in MacConkey agar, cetrimide agar, Slanetz agar, and salt agar. Then, they were incubated at $37 \pm 1^{\circ} \mathrm{C}$ for $24 \mathrm{~h}$. The characteristically distinct colonies were isolated and purified by subculturing in fresh media and incubating at $37 \pm 1^{\circ} \mathrm{C}$ for $18-24 \mathrm{~h}$ to obtain pure culture isolates according to the recommendations of Meunier et al. [10].

The cultural, morphological, biochemical, and physiological characterizations of the bacterial isolates were determined by classical biochemical techniques and the API (bioMérieux, France) according to the schemes of Cheesbrough [11].

2.4. Antibiogram of Isolated Bacteria. The antimicrobial susceptibility tests of the isolates were determined by using the disk diffusion test according to the methods of Bauer et al. [12]. An inoculum of each isolate (approximately $1 \times 108 \mathrm{cfu} / \mathrm{ml}$ ) was developed by using the McFarland Standard and aseptically flooded on the surface of sterile Mueller-Hinton Agar (Oxoid, England).

Twenty antibiotic disks (Oxoid, England) were tested: penicillin (1 IU), gentamicin $(10 \mu \mathrm{g})$, kanamycin $(30 \mu \mathrm{g})$, erythromycin $(15 \mu \mathrm{g})$, ampicillin $(10 \mu \mathrm{g})$, amoxicillin-clavulanic acid $(30 \mu \mathrm{g})$, cefoxitin $(30 \mu \mathrm{g})$, ceftazidime $(30 \mu \mathrm{g})$, ceftriaxone $(30 \mu \mathrm{g})$, cefepime $(30 \mu \mathrm{g})$, tetracyclin $(30 \mu \mathrm{g})$, levofloxacin $(5 \mu \mathrm{g})$, imipenem $(10 \mu \mathrm{g})$, piperacillin $(100 \mu \mathrm{g})$, piperacillin/tazobactam $(100 / 10 \mu \mathrm{g})$, ticarcillin $(75 / 10 \mu \mathrm{g})$, sulfamethoxazol/trimethoprim $(75 / 25 \mu \mathrm{g})$, ciprofloxacin $(5 \mu \mathrm{g})$, chloramphenicol $(30 \mu \mathrm{g})$, and fusidic acid $(10 \mu \mathrm{g})$.

Antibiotics were selected on the basis of local availability, literature, effectiveness, and the guidelines of the Clinical and Laboratory Standards Institute (CLSI). They were aseptically placed on the seeded plates and then incubated at $37 \pm 1^{\circ} \mathrm{C}$ for $18-24 \mathrm{~h}$. The zone diameters of the drugs were measured and interpreted by using the criteria published by the CLSI [13]. Phenotypic detection of the presence of extended-spectrum beta-lactamase (ESBL) in Enterobacteria isolates was performed in vitro by the disk diffusion method also known as double-disk synergy test (a disk approximation test) combining Augmentin (amoxicillin-clavulanic acid) with a third-generation cephalosporin. The appearances of a synergistic image between these antibiotics (champagne cork) reflect a production of ESBL by the strain [13].

Resistance to methicillin among $S$. aureus strains was investigated using a cefoxitin disk under standard susceptibility testing. Strains with an inhibition diameter of less than $22 \mathrm{~mm}$ were considered MRSA [13].

\section{Results}

A total of 200 samples distributed as follows were analyzed: 50, floor and wall surfaces; 46, bed surfaces; 35, door and window handles; 24, equipment; 10, faucets and washbasins; 
15 , bedside tables; and 20 other sites. Of these samples, 176 (88\%) showed positive cultures with 18 having mixed growth; 196 isolates were identified.

3.1. Distribution of Isolated Bacteria. From a bacteriological point of view, the positive threshold per department was 95\% (38/40) in medicine, $92.5 \%(37 / 40)$ in maternity, $90 \%$ $(36 / 40)$ in surgery, $87.5 \%(35 / 40)$ in emergencies, and $75 \%$ $(30 / 40)$ in operating rooms. Various bacterial pathogens have been isolated as shown in Table 1 .

A predominance of Gram-negative bacteria (GNB) with 101 isolates (51.5\%) of which $61.4 \%(62 / 101)$ are Enterobacteriaceae is distributed as follows: $30.6 \%(19 / 62)$ of Enterobacter spp., 29\% of Klebsiella spp. (18/62), 16.1\% (10/ 62) of Serratia spp., $12.9 \%$ (8/62) of Proteus spp., 8.1\% (5/62) of Citrobacter spp., and 3.2\% (2/62) are E. coli species. The other GNB are represented by the species of Acinetobacter with an incidence of $5.9 \%(6 / 101)$ and $17.8 \%(18 / 101)$ of Pseudomonas aeruginosa. However, Burkholderia cepacia, Stenotrophomonas maltophilia, and Aeromonas spp. are distributed as follows: $5(2.6 \%), 8(4.1 \%)$, and $2(1 \%)$, respectively. While 95 strains (48.5\%) were Gram positive consisting of Staphylococcus aureus with an incidence of $49.5 \%$ (47/95), 33.7\% (32/95) of coagulase-negative Staphylococcus (CoNS), 15.8\% of Bacillus strains (15/95), and a single strain of Streptococcus belonging to the Lancefield serological group D.

3.2. Antimicrobial Sensitivity Pattern of the Isolates. Table 2 illustrates the resistance profile of GNB with respect to several families of antibiotics. Enterobacteriaceae strains showed high resistance to ampicillin and amoxicillin-clavulanic acid, with resistance rates of $90.3 \%$ and $83.9 \%$, respectively, while they showed total sensitivity to imipenem and $32.3 \%$ (20/62) produced an extended-spectrum betalactamase (ESBL). It is also concluded, according to the current definition of MDR, that $44.4 \%$ (8/18) of Pseudomonas and $50 \%(3 / 6)$ of Acinetobacter are MDR, that is, strains resistant to at least three classes of antibiotics [14], while $44.7 \%(21 / 47)$ of $S$. aureus strains were methicillin resistant.

\section{Discussion}

The role of the environment in hosting and transmitting MDR organisms has become clearer through a series of publications linking environmental contamination to the increased risk of hospital-acquired infections. The incidence of antimicrobial resistance is also increasing and resulting in higher morbidity and mortality associated with nosocomial infections [15].

In this study, the overall prevalence of bacterial contamination in the different services is $88.4 \%$. At the national level, Saouide el Ayne et al. reported a contamination rate of $96.3 \%$. It is interesting to note here that the same rate was found by El Ouali Lalami et al. at the Fez city regional hospital. Elsewhere, similar studies conducted in Nigeria and Ethiopia reported lower rates of positivity at $46.7 \%$ and
$39.6 \%$, respectively [16-19]. Beyond Africa, a research carried out in Taiwan reflected a prevalence of $63.5 \%$. Another study conducted in seven hospitals in Iran revealed $57 \%$, and a research in a surgical setting at the Western General Hospital, in Scotland, in 2018, indicated a rate of 95.7\% [20-22]. This contamination thus varies, qualitatively and quantitatively over time, from one institution to another and within the same establishment, and according to the services, patients, care, and techniques practiced. This difference is also due to the high sensitivity of the method for isolating bacterial colonies subsequent to an enrichment step [10].

Along with the quality of the organic cleaning applied, surface contamination depends on many factors related to microorganisms and their viability (survival) in the environment favored by the formation of biofilms. The latter varies according to the type of bacteria and the nature of the contaminated surfaces. This environmental impact was favored by the formation of biofilms on the surfaces [23]. The bacteria found on the surfaces also depend on the quality of the air because the particles suspended in the air will inevitably end up deposited on the surfaces and all the more quickly when they are larger. Thus, besides the quality of the biocleaning, the surface samples of a room will reflect the efficiency or the failures of an air treatment system.

The acquisition of resistance to amoxicillin/clavulanate, the antibiotic with a very strong prescription in Morocco, is a worldwide phenomenon reported at substantially variable rates. In this study, resistance to amoxicillin-clavulanate (Augmentin) was $83.9 \%$. A similarly high rate $(76.4 \%)$ was found in Cameroon [24].

Concerning the strains of Enterobacteriaceae involved in the contamination of the different surfaces, 32.3\% (20/62) produced ESBL. This rate is close to that reported by the study conducted at the Cheikh Zaid Hospital, in Rabat, Morocco, in 2012, which found that 25.93\% of ESBLs were isolated from medical equipment samples [25]. The total sensitivity of strains to imipenem may be due to the fact that this drug is not an antibiotic commonly used in human medicine.

For S. aureus strains, $44.7 \%$ were identified as MRSA. This prevalence remains lower compared to that recorded by Worku et al., which is $73.7 \%$ [26]. This bacterium is one of the most commonly implicated agents in nosocomial infections. Recent estimates suggest MRSA causes between 11,000 and 18,000 deaths and 80,000 invasive infections in the US annually $[27,28]$. The proteins present in their cell walls for biofilm evasion of host immune responses and tissue-adhering abilities have enabled these organisms to survive and flourish in nature (https://bmcinfectdis.biomedcentral.com/ articles/10.1186/s12879-018-2980-5) [29]. The significant presence of CoNS at the surface level (16.3\%) could increase the danger of their involvement in nosocomial diseases, which is increasingly reported in the literature and which is accentuated by their MDR, which is also proven [30].

There is also a relatively high prevalence of resistance (50\%) in strains of Acinetobacter spp. Exposure of strains of this species to the selective pressure of potent antibiotics has 
TABLE 1: Total number of screened equipment and surfaces and organisms detected.

\begin{tabular}{|c|c|c|c|c|c|c|c|c|c|}
\hline \multirow[b]{2}{*}{ Gram } & \multicolumn{9}{|c|}{ Sampling site } \\
\hline & Organism detected & $\begin{array}{l}\text { Floor and } \\
\text { wall (50) }\end{array}$ & $\begin{array}{c}\text { Patient } \\
\text { beds } \\
(46) \\
\end{array}$ & $\begin{array}{l}\text { Bedside } \\
\text { table (15) }\end{array}$ & $\begin{array}{c}\text { Door/ } \\
\text { window } \\
\text { handle }(35)\end{array}$ & $\begin{array}{l}\text { Sinks and } \\
\text { taps (10) }\end{array}$ & $\begin{array}{l}\text { Hospital } \\
\text { equipment } \\
(24)\end{array}$ & $\begin{array}{c}\text { Other } \\
\text { items } \\
(20) \\
\end{array}$ & Total $=200$ \\
\hline \multirow{16}{*}{$\begin{array}{l}\text { Gram }+ \text { Total }=95 \\
(48.5 \%)\end{array}$} & $\begin{array}{l}\text { S. coagulase } \\
\text { negative }\end{array}$ & 12 & 7 & - & 4 & 2 & 3 & 4 & $32(16.3 \%)$ \\
\hline & Bacillus spp. & 8 & 3 & - & 2 & - & - & 2 & $15(7.7 \%)$ \\
\hline & S. aureus & 12 & 11 & 4 & 10 & - & 6 & 4 & $47(24 \%)$ \\
\hline & Streptococcus spp. & - & 01 & - & - & - & - & - & $01(0.5 \%)$ \\
\hline & Enterobacter spp. & 2 & 7 & 1 & 4 & 1 & 3 & 1 & $19(18.8 \%)$ \\
\hline & Klebsiella spp. & 3 & 1 & 2 & 4 & & 4 & 4 & $18(9.2 \%)$ \\
\hline & $\begin{array}{c}\text { Pseudomonas } \\
\text { aeruginosa }\end{array}$ & 3 & 6 & - & 2 & 2 & 2 & 3 & $18(8.1 \%)$ \\
\hline & Serratia spp. & 2 & 2 & 2 & 4 & - & - & - & $10(5.1 \%$ \\
\hline & Proteus spp. & 4 & - & 2 & 0 & - & 1 & 1 & $8(4.1 \%)$ \\
\hline & $\begin{array}{c}\text { Stenotrophomonas } \\
\text { maltophilia }\end{array}$ & 2 & - & 0 & 3 & - & - & 2 & $7(3.6 \%)$ \\
\hline & Acinetobacter spp. & 3 & - & - & - & 1 & - & 2 & $6(3.1 \%)$ \\
\hline & $\begin{array}{c}\text { Burkholderia } \\
\text { cepacia }\end{array}$ & 4 & - & - & 2 & - & - & - & $6(3.1 \%)$ \\
\hline & Citrobacter spp. & 1 & - & - & - & 1 & 3 & - & $5(2.6 \%)$ \\
\hline & E. coli & - & 1 & 1 & - & - & - & - & $2(1 \%)$ \\
\hline & Aeromonas spp. & - & - & - & - & 2 & - & - & $2(1 \%)$ \\
\hline & Total $=196$ & $56^{*}$ & $39^{*}$ & 12 & $35^{*}$ & 9 & $22^{*}$ & $23^{*}$ & 196 \\
\hline
\end{tabular}

Other items: objects that are not used directly to the patient such as scialytics, trolleys, and some closet; -, no detection of specified organism in this particular object; * mixed growth of bacteria.

gradually led to the global prevalence of strains resistant to all $\beta$-lactamins and carbapenems. This resistance is due to combined mechanisms, generally including impermeability of the cell membrane, increased expression of efflux pumps, and the production of enzyme $\beta$-lactamase of several types [31].

In the medical services, $95 \%(38 / 40)$ of the sites were contaminated with 8 E-ESBL, 9 MRSA, and 5 MDR $P$. aeruginosa, which, on the one hand, could be related to the high activity taking place in these services, and on the other, to the high prescription of antibiotics, especially for patients hospitalized following diabetic foot infections. In fact, when patients are colonized, and especially when there is a patient infection, their immediate environment is generally highly contaminated by MDR bacteria as well as by those with frequent natural antibiotic resistance $[32,33]$.

For the operating theatre, the level of contamination discovered is also high (75\%) and thus constitutes a high risk of occurrence of a surgical site infection (ISO), even worse if $38.1 \%(8 / 21)$ of MRSA were isolated from the same service. Although the role played by surface contamination in the genesis of ISOs is difficult to assess, a survey of the prevalence of nosocomial infections conducted at the Hassan II University Hospital, in Fez, Morocco, revealed that ISOs were mostly affected by nosocomial infections (46\%) [34].

The evolution of the Gram-negative bacilli (GNB) resistance antibiotics reveals that MDR has remained, however, much more worrying in recent years. In February 2017, the WHO classified P. aeruginosa, Acinetobacter baumannii, and E-ESBL as the most critical pathogens from the point of view of antimicrobial resistance and for which the research and development of new antibiotics is a priority [35]. This group is composed of bacteria resistant to many extendedspectrum antibiotics including carbapenems, widely used to fight against MDR bacteria in hospitals.

The fact is that the emergence of MDR at the hospital is a real danger to public health if nothing is done to limit this spread. It may lead to epidemics difficult to eradicate, particularly with the bidirectional translocation of these bacteria between the hospital and the community. Furthermore, by mastering the method of predisinfection and the cleaning of reusable medical devices, the population of microorganisms can be reduced and the subsequent stage of disinfection or sterilization of the equipment can be facilitated. Also, extremely close attention should be paid to hospital hygiene training: hand hygiene, the use of personal protective equipment, and regulatory requirements, such as the safe disposal of medical waste and the safe handling of laundry [36].

It is noteworthy here that owing to rather limited variables in this study, it was not possible to determine the factors associated with the significant contamination of the hospital environment. Similarly, antimicrobial susceptibility patterns have also been determined with respect to just bacteria considered to present a high risk for patients to develop nosocomial diseases. Thus, we recommend extending the determination of the susceptibility profile to all bacteria associated with surface contamination and the development of their characteristics in order that we may be 
TABle 2: Antibiotic susceptibility pattern of GNB and Staphylococcus aureus.

\begin{tabular}{|c|c|c|c|c|c|c|c|c|c|}
\hline \multirow[b]{2}{*}{ Antibiotics } & \multicolumn{9}{|c|}{ Enterobacteriaceae $(n=62)$} \\
\hline & $\begin{array}{c}\text { Enterobacter } \\
\text { spp. } \\
(n=19)\end{array}$ & $\begin{array}{c}\text { Klebsiella } \\
\text { spp. } \\
(n=18)\end{array}$ & $\begin{array}{c}\text { Serratia } \\
\text { spp. } \\
(n=10)\end{array}$ & $\begin{array}{c}\text { Proteus } \\
\text { spp. } \\
(n=8)\end{array}$ & $\begin{array}{c}\text { Citrobacter } \\
\text { spp. } \\
(n=5)\end{array}$ & $\begin{array}{l}\text { E. coli } \\
(n=2)\end{array}$ & $\begin{array}{l}P . \text { aeruginosa } \\
(n=18)\end{array}$ & $\begin{array}{l}\text { Acinetobacter } \\
\quad(n=6)\end{array}$ & $\begin{array}{c}\text { S. aureus } \\
(n=47)\end{array}$ \\
\hline Penicillin & - & - & - & - & - & - & - & - & $\begin{array}{c}25 \\
(53.2 \%)\end{array}$ \\
\hline Ampicillin & $19(100 \%)$ & $18(100 \%)$ & $10(10 \%)$ & $5(63 \%)$ & $4(80 \%)$ & $\begin{array}{c}1 \\
(50 \%)\end{array}$ & - & - & - \\
\hline $\begin{array}{l}\text { Amoxicillin-clavulanic } \\
\text { acid }\end{array}$ & $18(95 \%)$ & $\begin{array}{c}15 \\
(83.3 \%)\end{array}$ & $\begin{array}{c}10 \\
(100 \%)\end{array}$ & $3(38 \%)$ & $5(100 \%)$ & $\begin{array}{c}1 \\
(50 \%)\end{array}$ & - & - & - \\
\hline Piperacillin & $7(36.8 \%)$ & $\begin{array}{c}10 \\
(55.6 \%)\end{array}$ & $\begin{array}{c}10 \\
(100 \%)\end{array}$ & 00 & $3(60 \%)$ & $\begin{array}{c}1 \\
(50 \%)\end{array}$ & $8(44.4 \%)$ & $5(83 \%)$ & - \\
\hline Piperacillin + tazobactam & $4(21 \%)$ & $1(5.6 \%)$ & $2(20 \%)$ & 00 & $1(20 \%)$ & 00 & $4(22.2 \%)$ & $3(50 \%)$ & - \\
\hline Ticarcillin & $11(57.9 \%)$ & $\begin{array}{c}13 \\
(72.2 \%)\end{array}$ & $9(90 \%)$ & 00 & $3(60 \%)$ & 00 & $8(44.4 \%)$ & $5(83 \%)$ & - \\
\hline Ceftriaxone & $11(57.9 \%)$ & $5(27.8 \%)$ & $2(20 \%)$ & $4(50 \%)$ & $1(20 \%)$ & 00 & - & $4(67 \%)$ & - \\
\hline Ceftazidime & $8(42.1 \%)$ & $6(33.3 \%)$ & $2(20 \%)$ & $0(13 \%)$ & $1(20 \%)$ & $\begin{array}{c}1 \\
(50 \%)\end{array}$ & $8(44.4 \%)$ & $4(67 \%)$ & - \\
\hline Cefepime & 00 & 00 & 00 & 00 & 00 & 00 & 00 & 00 & - \\
\hline Cefoxitin & $8(42.1 \%)$ & $6(33.3 \%)$ & $8(80 \%)$ & 00 & $1(20 \%)$ & $\begin{array}{c}2 \\
(100 \%)\end{array}$ & - & - & $\begin{array}{c}21 \\
(44.7 \%)\end{array}$ \\
\hline Erythromycin & - & - & - & - & - & - & - & - & $\begin{array}{c}26 \\
(55.3 \%)\end{array}$ \\
\hline Imipenem & $00(00 \%)$ & $00(0 \%)$ & $00(0 \%)$ & 00 & 00 & 00 & $1(5.6 \%)$ & $3(50 \%)$ & - \\
\hline Chloramphenicol & $6(31.6 \%)$ & $\begin{array}{c}10 \\
(55.6 \%)\end{array}$ & $00(0 \%)$ & $5(63 \%)$ & $2(40 \%)$ & 00 & - & - & $\begin{array}{c}21 \\
(44.7 \%)\end{array}$ \\
\hline Gentamicin & $10(52.6 \%)$ & $1(5.6 \%)$ & $8(80 \%)$ & $2(25 \%)$ & $1(20 \%)$ & 00 & $8(44.4 \%)$ & $2(33.3 \%)$ & $\begin{array}{c}19 \\
(40.4 \%)\end{array}$ \\
\hline Kanamycin & - & - & - & - & - & - & - & - & $\begin{array}{c}27 \\
(57.4 \%)\end{array}$ \\
\hline Tetracycline & $14(73.7 \%)$ & $7(38.9 \%)$ & $7(70 \%)$ & $2(25 \%)$ & $1(20 \%)$ & $\begin{array}{c}1 \\
(50 \%)\end{array}$ & - & $5(83 \%)$ & $\begin{array}{c}25 \\
(53.2 \%)\end{array}$ \\
\hline Ciprofloxacin & $5(26.3 \%)$ & $6(33.3 \%)$ & $5(50 \%)$ & $7(88 \%)$ & $3(60 \%)$ & 00 & $10(55.6 \%)$ & $2(33.3 \%)$ & $\begin{array}{c}29 \\
(61.7 \%)\end{array}$ \\
\hline Levofloxacin & $4(21 \%)$ & $4(22.2 \%)$ & $2(20 \%)$ & $1(13 \%)$ & $1(20 \%)$ & 00 & $8(44.4 \%)$ & $5(83 \%)$ & $\begin{array}{c}6 \\
(12.8 \%)\end{array}$ \\
\hline Fusidic acid & - & - & - & - & - & - & - & - & $\begin{array}{c}16 \\
(34.04 \%)\end{array}$ \\
\hline $\begin{array}{l}\text { Trimethoprim- } \\
\text { sulfamethoxazol }\end{array}$ & $9(47.37 \%)$ & $8(44.4 \%)$ & $2(20 \%)$ & $3(38 \%)$ & $2(40 \%)$ & $\begin{array}{c}2 \\
(100 \%)\end{array}$ & - & - & $\begin{array}{c}19 \\
(40.4 \%)\end{array}$ \\
\hline ESBL & $8(42.11 \%)$ & $9(50 \%)$ & $2(20 \%)$ & 00 & 00 & $\begin{array}{c}1 \\
(50 \%)\end{array}$ & - & - & - \\
\hline
\end{tabular}

-: not applicable; ESBL: extended-spectrum beta-lactamase.

able to decipher the genes involved in antimicrobial resistance and their transmission mode.

\section{Conclusion}

In brief, in view of the results of this first study carried out at the hospital in Mohammedia and owing to the high levels of resistance in all types of isolated bacteria, which affect different services, it is important and urgent to assess and strengthen infection-prevention practices. Moreover, current hand-hygiene guidelines and recommendations for surface cleaning and disinfection should be thoroughly followed and adhered to in managing outbreaks due to these emerging pathogens.

\section{Data Availability}

All relevant data generated and analyzed during this study are included in this manuscript.

\section{Conflicts of Interest}

The authors declare that they have no conflicts of interest.

\section{Acknowledgments}

The authors thank everyone who has contributed in the realization of this work including the Director of the hospital and the heads of the departments involved in this study. 


\section{References}

[1] World Health Organization, Prevention of Hospital-Acquired Infections, World Health Organization, Geneva,Switzerland, 2015, http://www.who.int/csr/resources/ publications/whocdscsreph200212.pdf.

[2] L. Sehulster and R. Y. Chinn, "Guidelines for environmental infection control in health-care facilities: recommendations of $\mathrm{CDC}$ and the healthcare infection control practices advisory committee (HICPAC)," MMWR Recommendations and Reports, vol. 52, no. 10, pp. 1-42, 2003.

[3] H. E. L. D. Boer, C. M. van Elzelingen-Dekker, C. M. F. van Rheenen-Verberg, and L. Spanjaard, "Use of gaseous ozone for eradication of methicillin-resistant Staphylococcus aureus from the home environment of a colonized hospital employee," Infection Control \& Hospital Epidemiology, vol. 27, no. 10, pp. 1120-1122, 2006.

[4] E. Caselli, L. Arnoldo, C. Rognoni et al., "Impact of a probiotic-based hospital sanitation on antimicrobial resistance and HAI-associated antimicrobial consumption and costs: a multicenter study," Infection and Drug Resistance, vol. 12, pp. 501-510, 2019.

[5] J. Amrani, Résultats de l'Enquête de Prévalence des Infections Nosocomiales au Niveau de 24 Hôpitaux, Ministère de la Santé, Rabat, Morocco, 1994.

[6] A. Vasudevan, A. Mukhopadhyay, J. Li, E. G. Y. Yuen, and P. A. Tambyah, "A prediction tool for nosocomial multi-drug resistant Gram-negative bacilli infections in critically ill patients-prospective observational study," BMC Infectious Diseases, vol. 14, no. 1, p. 615, 2014.

[7] L. Bernard, A. Kereveur, D. Durand et al., "Bacterial contamination of hospital stethoscope," Infection Control \& Hospital Epidemiology, vol. 20, no. 9, pp. 274-276, 1999.

[8] A. Bhalla, N. J. Pultz, D. M. Gries et al., "Acquisition of nosocomial pathogens on hands after contact with environmental surfaces near hospitalized patients," Infection Control \& Hospital Epidemiology, vol. 25, no. 2, pp. 164-167, 2004.

[9] International Organization for Standardization (ISO), Clean Rooms and Associated Controlled Environments: Biocontamination Control. Part 1: General Principles and Methods, International Organization for Standardization (ISO), Geneva, Switzerland, 2003, http://www.iso.org.

[10] O. Meunier, C. Hernandez, M. Piroird, R. Heilig, D. Steinbach, and A. Freyd, "Prélèvements bactériologiques des surfaces: importance de l'étape d'enrichissement et du choix des milieux de culture," Annales de Biologie Clinique, vol. 63, no. 5, pp. 481-486, 2005.

[11] M. Cheesbrough, District Laboratory Practice in Tropical Countries Part 2, Cambridge University Press, Cambridge, UK, 2006.

[12] A. W. Bauer, W. M. M. Kirby, J. C. Sherris, and M. Turck, "Antibiotic susceptibility testing by a standardized single disk method," American Journal of Clinical Pathology, vol. 45, no. 4, pp. 493-496, 1966.

[13] AACC, Performance Standards for Antimicrobial Susceptibility Testing; Twenty-Fourth Informational Supplements (M100-S24), AACC, Washington, DC, USA, 2014.

[14] A.-P. Magiorakos, A. Srinivasan, R. B. Carey et al., "Multidrug-resistant, extensively drug-resistant and pandrug-resistant bacteria: an international expert proposal for interim standard definitions for acquired resistance," Clinical Microbiology and Infection, vol. 18, no. 3, pp. 268-281, 2012.

[15] R. F. Chemaly, S. Simmons, C. Dale Jr. et al., "The role of the healthcare environment in the spread of multidrug-resistant organisms: update on current best practices for containment," Therapeutic Advances in Infectious Disease, vol. 2, no. 3-4, pp. 79-90, 2014.

[16] N. Saouide el Ayne, A. Echchelh, A. Chaouch, N. Auajjar, S. Hamama, and A. Soulaymani, "Role de l'environnement hospitalier dans la prevention des infections nosocomiales: surveillance de la flore des surfaces a l'hopital el idrissi de Kenitra-MAROC," European Scientific Journal, vol. 10, no. 9, pp. 238-247, 2014.

[17] A. El Ouali Lalami, H. Touijer, F. El-Akhal et al., "Microbiological monitoring of environment surfaces in a hospital in Fez city, Morocco," Journal of Materials and Environmental Science, vol. 7, no. 1, pp. 123-130, 2016.

[18] K. Ochie and C. C. Ohagwu, "Contamination of X-ray equipment and accessories with nosocomial bacteria and the effectiveness of common disinfecting agents," African Journal of Basic and Applied Sciences, vol. 1, no. 1-2, pp. 31-35, 2009.

[19] H. Getachew, A. Derbie, and D. Mekonnen, "Corrigendum to "surfaces and air bacteriology of selected wards at a referral hospital, Northwest Ethiopia: a cross sectional study", International Journal of Microbiology, vol. 2018, Article ID 2190787, 1 page, 2018.

[20] K. H. Chen, L. R. Chen, and Y. K. Wang, "Contamination of medical charts: an important source of potential infection in hospitals," PLoS One, vol. 9, no. 2, Article ID e78512, 2014.

[21] A. Ekrami, A. Kayedani, M. Jahangir, E. Kalantar, and M. Jalali, "Isolation of common aerobic bacterial pathogens from the environment of seven hospitals, Ahvaz, Iran. Jundishapur," Journal of Microbiology, vol. 4, no. 2, pp. 75-82, 2011.

[22] R. R. W. Brady, P. Kalima, N. N. Damani, R. G. Wilson, and M. G. Dunlop, "Bacterial contamination of hospital bedcontrol handsets in a surgical setting: a potential marker of contamination of the healthcare environment," The Annals of The Royal College of Surgeons of England, vol. 89, no. 7, pp. 656-660, 2007.

[23] X. Shi and X. Zhu, "Biofilm formation and food safety in food industries," Trends in Food Science \& Technology, vol. 20, no. 9, pp. 407-413, 2009.

[24] A. J. Kihla, P. J. Ngunde, S. E. Mbianda, G. Nkwelang, and R. N. Ndip, "Risk factors for wound infection in health care facilities in Buea, Cameroon: aerobic bacterial pathogens and antibiogram of isolates," Pan African Medical Journal, vol. 18, no. 1, 2014.

[25] N. Bennani Mechita, R. Razine, A. Saadi et al., "Evolution of extended spectrum beta-lactamase enterobacteriaceae in the Hospital Cheikh Zaid from 2009 to 2011," International Journal of Epidemiology, vol. 44, no. 1, pp. i268-i269, 2015.

[26] T. Worku, D. Derseh, and A. Kumalo, "Bacterial profile and antimicrobial susceptibility pattern of the isolates from stethoscope, thermometer, and inanimate surfaces of MizanTepi University Teaching Hospital, Southwest Ethiopia," International Journal of Microbiology, vol. 2018, Article ID 9824251, 7 pages, 2018.

[27] Center for Disease Control and Prevention, Antibiotic Resistance Threats in the United States, CDC, Atlanta, GA, USA, 2013, http://www.cdc.gov/drugresistance/threat-report-2013/.

[28] R. Dantes, Y. Mu, R. Belflower et al., "National burden of invasive methicillin-resistant Staphylococcus aureus infections, United States, 2011," JAMA Internal Medicine, vol. 173, no. 21, pp. 1970-1978, 2013.

[29] T. J. Foster, J. A. Geoghegan, V. K. Ganesh, and M. Höök, "Adhesion, invasion and evasion: the many functions of the surface proteins of Staphylococcus aureus," Nature Reviews Microbiology, vol. 12, no. 1, pp. 49-62, 2014. 
[30] D. J. Diekema, M. A. Pfaller, F. J. Schmitz et al., "Survey of infections due to Staphylococcus species: frequency of occurrence and antimicrobial susceptibility of isolates collected in the United States, Canada, Latin America, Europe, and the Western Pacific region for the SENTRY antimicrobial surveillance program, 1997-1999," Clinical Infectious Diseases, vol. 32, no. 2, pp. S114-S132, 2001.

[31] R. Zarrilli, S. Pournaras, M. Giannouli, and A. Tsakris, "Global evolution of multidrug-resistant Acinetobacter baumannii clonal lineages," International Journal of Antimicrobial Agents, vol. 41, no. 1, pp. 11-19, 2013.

[32] D. Talon, "The role of the hospital environment in the epidemiology of multi-resistant bacteria," Journal of Hospital Infection, vol. 43, no. 1, pp. 13-17, 1999.

[33] D. J. Weber and W. A. Rutala, "Role of environmental contamination in the transmission of vancomycin-resistant Enterococci," Infection Control and Hospital Epidemiology, vol. 18, no. 5, pp. 306-309, 1997.

[34] K. El Rhazi, S. El Fakir, M. Berraho et al., "Prevalence and risk factors for nosocomial infections in Hassan II University Hospital, Fes, Morocco," Eastern Mediterranean Health Journal, vol. 13, no. 1, pp. 56-63, 2007.

[35] World Health Organization, Global Priority List of AntibioticResistant Bacteria to Guide Research, Discovery, and Development of New Antibiotics, World Health Organization, Geneva, Switzerland, 2017, https://www.who.int/medicines/publications/ WHO-PPLShortSummary_25FebET_NM_WHO.pdf.

[36] Norme ISO 14698-1, Salles Propres et Environnement Maîtrisés Apparentés-Maîtrise de la Biocontamination, AFNOR, Paris, France, 2003. 


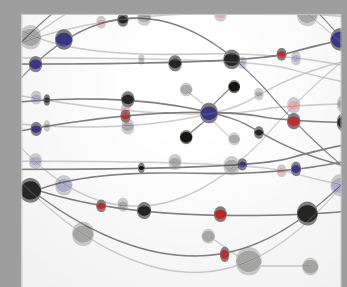

The Scientific World Journal
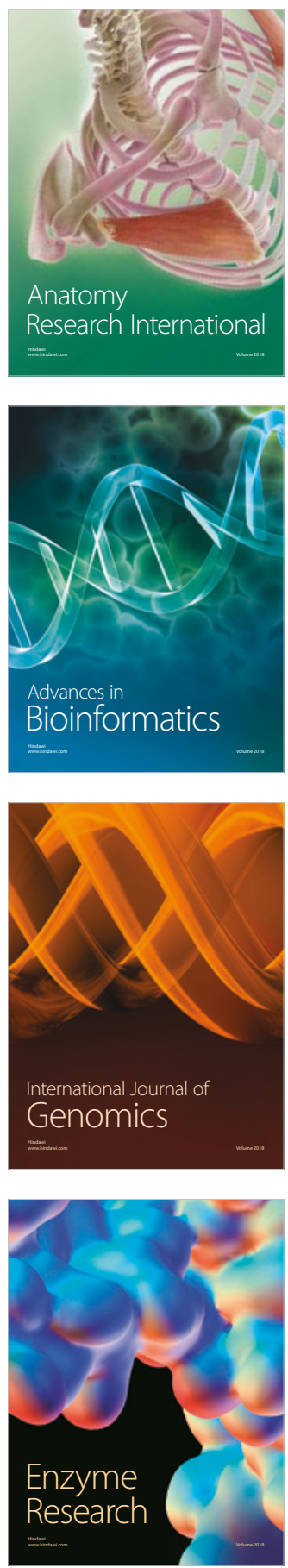
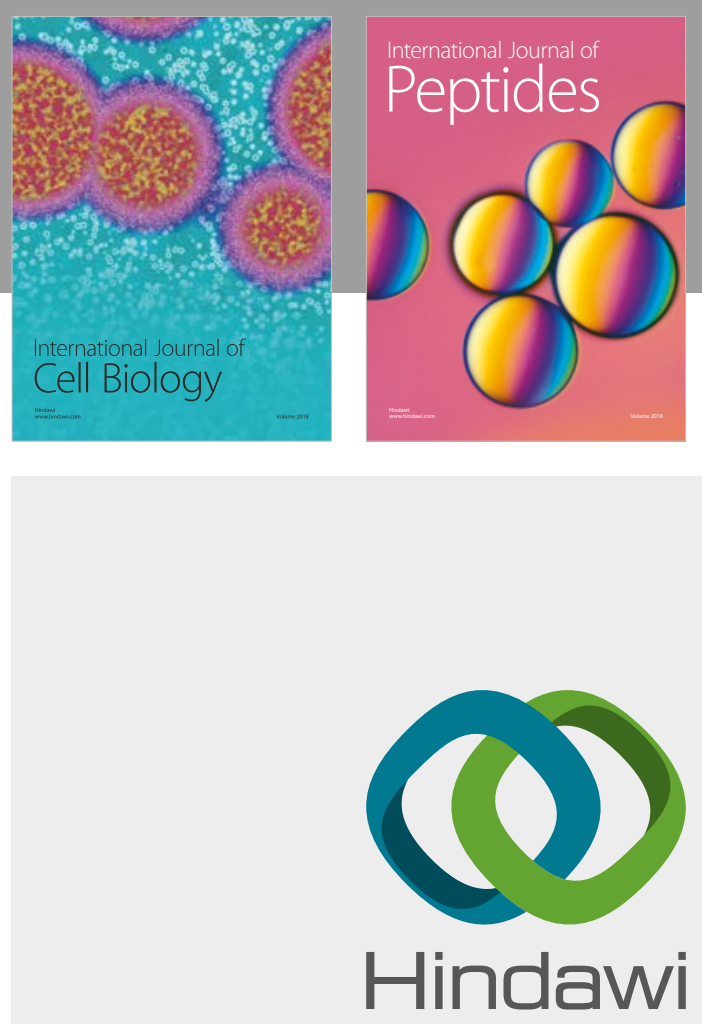

Submit your manuscripts at

www.hindawi.com
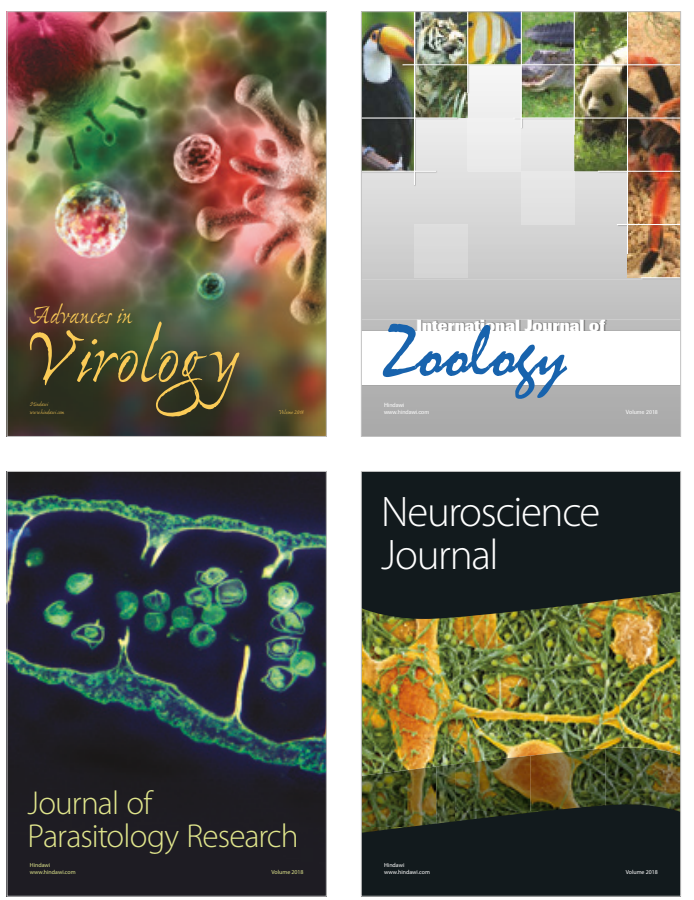
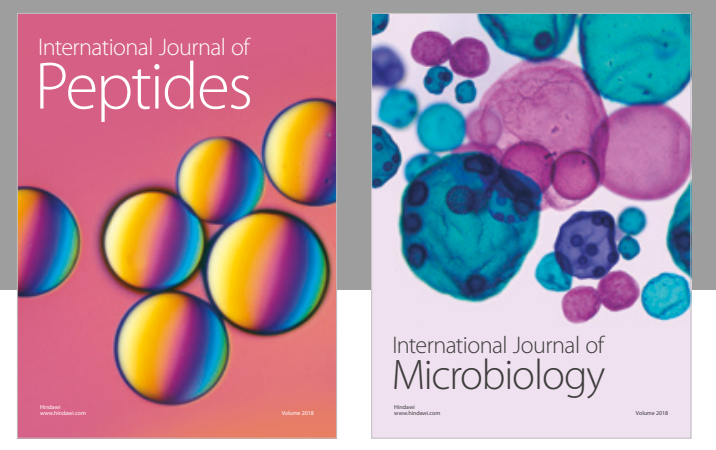

nternational Journal of Microbiology
Journal of
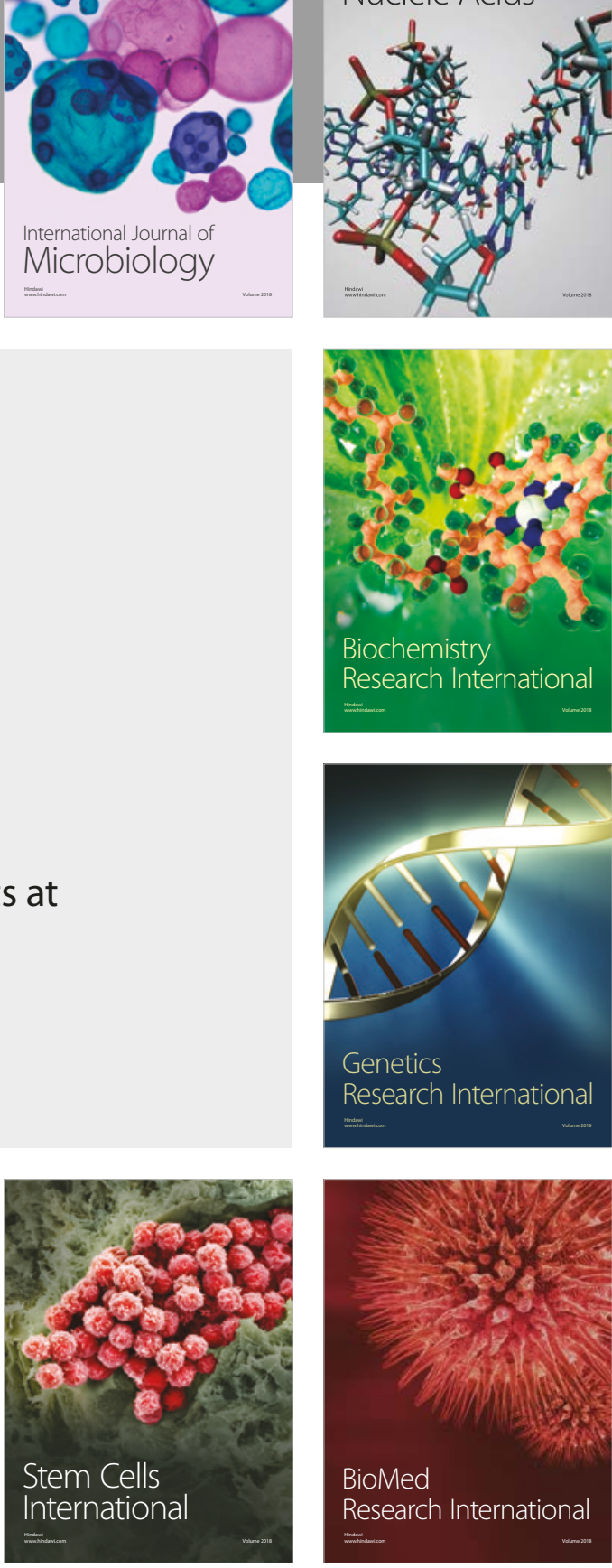
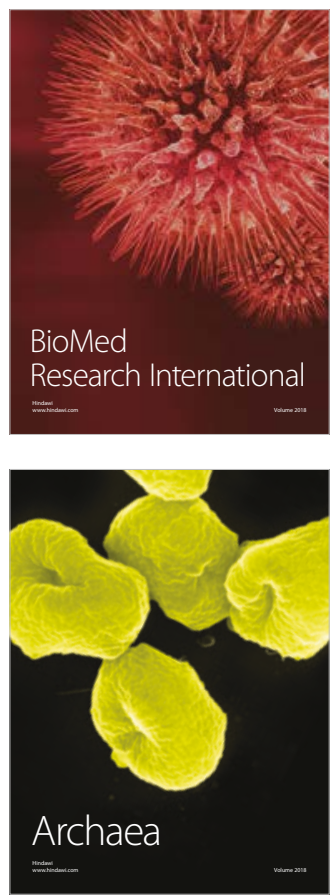